\title{
The issue of gender approach in pedagogical practice (on the example of the education system of foreign countries)
}

\section{Shokhsanam BARATOVA ${ }^{1}$}

Samarkand State University

\begin{tabular}{l} 
ARTICLE INFO \\
\hline Article history: \\
Received February 2021 \\
Received in revised form \\
20 February 2021 \\
Accepted 15 March 2021 \\
Available online \\
15 April 2021
\end{tabular}

\section{Keywords:}

gender equality,

gender approach

in education,

readiness to implement

gender approach,

teacher representation

in gender orientation

in education.

\begin{abstract}
Achieving gender equality around the world is becoming a central point of development of the country and society and an important part of the state strategy, and data based on the gender model of these symmetrical and balanced inclusive aspects of men and women are analyzed.
\end{abstract}

2181-1415/(C) 2021 in Science LLC.

This is an open access article under the Attribution 4.0 International (CC BY 4.0) license (https://creativecommons.org/licenses/by/4.0/deed.ru)

\section{Pedagogika amaliyotida gender yondashuv masalasi (chet davlatlarning ta'lim tizimi misolida)}

\section{Kalit so'zlar:}

gender tenglik,

ta'limdagi gender

yondashuv,

gender yondashuvni amalga oshirishga tayyorlik,

o'qituvchilarning ta'lim dagi gender yo'nalishi bo'yicha vakili.
ANNOTATSIYA

Butun dunyoda gender tengligiga erishish mamlakat va jamiyat taraqqiyotining markaziy nuqtasiga aylanayotganligi va davlat strategiyasining muhim qismini tashkil qilishi hamda bu erkaklar va ayollarni nosimmetrik va muvozanatli inklyuziv jihatlarining gender modeliga asoslangan ma'lumotlari tahlil qilingan.

\footnotetext{
${ }^{1}$ Doctoral student in the history of pedagogical education at Samarkand State University, Samarkand, Uzbekistan.
} 


\section{Вопрос гендерного подхода в педагогической практике (на примере системы образования зарубежных стран)}

\author{
Ключевые слова: \\ гендерное равенство, \\ гендерный подход \\ в образовании, \\ готовность к реализации \\ гендерного подхода, \\ представительство \\ учителей в гендерной \\ ориентации \\ в образовании.
}

\section{АННОТАЦИЯ}

Достижение гендерного равенства во всем мире
становится центральной точкой развития страны и
общества и важной частью государственной стратегии и
анализируются данные, основанные на гендерной модели
этих симметричных и сбалансированных инклюзивных
аспектов мужчин и женщин.

General formulation of the problem and its connection with important scientific and practical problems. In the categorical-theoretical apparatus of pedagogical science, the concept of "Gender". Gender studies have become an integral part of all human sciences, including pedagogical science. In addition, in the aggregate of the means of scientific support of modern education, the theory of the gender approach is increasingly asserting itself as a methodological orientation in teaching [1], [2], [3], [4].

Using the concept of "hidden curriculum", advocates of a gender approach in their research show how the education system at all its levels (from kindergarten to academies and universities) demonstrates the unequal status of men and women in society and contributes to the preservation of and reproduction of established gender stereotypes [2], [4], [5],[6], [7], [8], [9].

The studies of school practice show that, in terms of the values of gender equality, it needs significant modernization. That is why the application of a gender approach in the educational sphere is currently considered as a way to improve the level and quality of education of male and female students. The importance of reforming the education system taking into account the inclusion of gender approaches is also indicated in the Gender Strategy of the Russian Federation [10].

In addition, such Russian researchers as I.S. Kon [11], O.M. Zdravomyslova-Stayunina [12], L.V. Shtyleva [2], L.V. Popova [13], S.G. Aivazova [14], G.G. Silaste [15], E.N. Kamenskaya [3] and others in their works note that over the past decades in the life of Russian society there have been significant changes in socio-role relations: there is a rethinking of the place and role of women in various social spheres, the rigidity in the division of labor has decreased, the ego is growing-litarization of marriage and family relations, cultural stereotypes of masculinity and femininity have become less rigid and polar.

Comprehension of the pedagogical process from the standpoint of the concept of "gender" is of fundamental importance, since many ideas about professional selfdetermination, life strategy, access to resources and power, which are based on a sociosexual orientation, are formed at school. The implementation of a gender approach in school will allow to form an idea that gender is not a basis for discrimination based on any criterion or indicator, that it enables women and men to enjoy human rights in the fullness of this concept, gives rise to forces for free choice of paths and forms of self-realization at the level of their unique individuality. 
As I.V. Kostikova, "the point is not that representatives of different genders need a differentiated approach on the part of the teacher, but that they have to face a complex world of changing gender stereotypes that conflict with personal desires and inclinations person. To explain the nature of stereotypes, to show their variability and social conditioning these are the tasks of the gender approach in education" [16].

The gender aspect of rethinking pedagogical science and practice is most fully represented in the theory and methodology of the gender approach in school education, developed by L.V. Shtylevoy [2]. The researcher was the first to attempt to apply a gender approach in pedagogy and education. The goal of the gender approach in education is to deconstruct the traditional cultural constraints on the development of the potential of an individual depending on gender, to comprehend and create conditions for maximum selfrealization and disclosure of the abilities of girls and boys in the process of pedagogical interaction. Implementation gender approach and gender analysis in education, according to L.V. Shtyleva, will contribute not only to gender equality in society, but also, which is important, will make positive changes in gender relations in general, will serve as an impetus for the harmonious development of the individual in the process of education.

Therefore, understanding gender issues and mastering the main provisions of the gender approach is becoming an urgent task in the field of training specialists who are professionally involved in training and educating the younger generation.

In these conditions, it becomes urgent to form teachers' understanding of the need for a gender approach and the attitude towards its implementation; meaningful and methodological psychological and pedagogical preparation of future teachers for the implementation of a gender approach in teaching. To solve these problems, it is required to use new organizational forms and effective teaching technologies, to create teaching aids, textbooks, additional training courses, along with mandatory curriculum courses. An equally important area is the improvement of the psychological and pedagogical qualifications and skills of teachers, associated with the formation of the teacher's readiness to implement a gender approach in teaching schoolchildren.

It should be noted that the teacher's readiness to implement a gender approach in teaching schoolchildren is understood as a systemic education of the teacher's personality, which integrates knowledge of the basics of gender aspects of pedagogy and psychology, the need and ability to apply them in practical pedagogical activity, the ability to solve the problems of this activity at a high level. - com at a professional level, striving for self-education and self-education in this direction.

Analysis of recent studies and publications, which considered aspects of this problem and on which the author justifies; highlighting previously unsolved parts of the general problem. In recent decades, gender education has gradually "penetrated" the higher education system. By gender education, following scientists who have experience in this direction [17], we mean an educational model that takes into account gender interests, takes into account the presence of gender problems in the social development of society and the education system, and searches for ways to solve them ... Gender education is education aimed at mastering by students the basics of the gender concept and manifestations of the regularities of gender relations in society, the development of cultural tolerance and an egalitarian worldview. 
In addition, mastering the basics of gender knowledge corresponds to the main goals of modernizing higher education, the tasks of introducing the principles of the Bologna Agreement into the educational process and improving the quality of university education.

Some Russian universities and institutes of higher education operate gender centers and laboratories, hold scientific conferences and seminars on gender studies, teach gender courses, and publish textbooks on gender subjects. For example, the Department of Feminology of Ivanovo State University (O.A. Khasbulatova), the Laboratory for the Development of Gender Education of the Pedagogical Faculty of Moscow State University, make their contribution to the rapprochement of gender education with Russian reality. M.V. Lomonosov (I.V. Kostikova), St. Petersburg State Pedagogical University named after A.I. Herzen (I.S. Kletsina), Murmansk State Pedagogical Institute FPK and PPRO (L.V.Shtyleva), Research Center for State Pedagogical Sciences at Volgograd State Pedagogical University (L.I. Stolyarchuk), Research Laboratory of Psychological Pedagogy - Institute for Advanced Studies and Retraining of Educators (UIPKPRO, Ulyanovsk), the Center for Gender Studies in Ivanovo (O.V. Shnyrova), the Tver Center for Women's History and Gender Studies in the Tver State University (V.I. Uspenskaya), St. Petersburg Language Institute (I. Yukina), Saratov researchers, and many others. dr.

I.S. Kletsina [18] notes that the methodological component of practical orientation of gender education is aimed at solving problems associated with the formation and development of students' skills in gender analysis and education. Personally oriented orientation of gender education provides for the development of gender competence in trainees as a personality characteristic, which is manifested in the sphere of inter-sex interaction.

However, as Shnyrova accurately noted [19], despite the recent development of gender education in Russia, it is still very early to talk about gender pedagogy as an independent branch of science, "specially organized, purposeful activity for the formation of a person, forms and methods upbringing, education and training". Science that at the theoretical level generalizes the experience of gender education does not yet exist.

Gender education in higher pedagogical education, in our opinion, is one of the determining factors in the spread of the gender approach in general education schools. Purposeful systematic preparation of a future teacher for the implementation of a gender approach can be considered as an important area of modernization of higher pedagogical education. However, an analysis of pedagogical periodicals showed that over the past fifteen years, only a few programs on gender education for school teachers and students of pedagogical universities have been published: the program of the special course "Fundamentals of Gender Pedagogy" [20], FPK for educational workers [21], course "Gender socialization and education: theory and practice" for students of higher educational institutions of a pedagogical profile[22].

Nevertheless, all the positive and scarce experience of integrating a gender approach into teacher education cannot give a quick result. Our attempt to search for scientific research concerning the practical application of the gender approach in the pedagogical practice of teachers was not crowned with success.

Formation of the goals of the article (setting the task). This study was conducted to identify teachers' perceptions of gender mainstreaming in education. In psychology, a representation is understood as a visual image of an object or phenomenon (event) that arises on the basis of past experience (given sensations and perceptions) by reproducing 
it in memory or in the imagination [23]. Thus, the basis of ideas is always the previous experience of a person.

To identify teachers' perceptions of a gender approach in education, we have developed a questionnaire that includes the following questions:

- From what source did you first hear the word

- "Gender"?

- Continue with "Gender is ..."

- Continue the phrase: Gender approach in education is ...

- Continue the phrase: Gender approach in education is necessary because ...

- Continue the phrase: Gender approach in education is difficult, because ...

- List the areas of professional activity in which the teacher can use the gender approach most effectively.

- What do you think, do you use in your teacher gogic and sociological diagnostics of Ulyanovsk gical practice gender approach?

The survey was attended by 65 teachers working in schools in the Primorsky and Khabarovsk Territories, as well as in the Ussuriysk Suvorov School. A total of 44 women and 21 men, aged 20 to 60, who had a teaching experience of 1 to 40 years, were interviewed. The average age of the respondents is 42.5 years, the average teaching experience is 18.5 years.

$86 \%$ of the interviewed teachers have a pedagogical education, which they received at the Ussuri State Pedagogical Institute (34\%), at the Blagoveshchensk State Pedagogical Institute (12.5\%), at the Komsomolsk-on-Amur State Pedagogical University (9\%), at the Khabarovsk State Pedagogical Institute (3.6\%), the Spassk Pedagogical School (7 \%) and other professional and pedagogical institutions in Russia. $14 \%$ of respondents have a university, non-pedagogical education (chemist, philologist), technical education (technician, radio technician, construction technician-technologist), as well as education received in various fields of military engineering and management.

Presentation of the main material of the research with full justification of the scientific results obtained. Among the teachers surveyed, $21.5 \%$ noted that before the survey they had not heard such a word as "gender". $37 \%$ of respondents first encountered this concept during their studies at a university or while taking advanced training courses, and $32 \%$ - in the process of self-education. $49 \%$ of teachers who took part in the study noted the mass media and the Internet as a source of information on the concept of "gender", $15 \%$ - colleagues at work, friends, acquaintances, $7.7 \%$ - professional literature.

Thus, only one third of teachers received information about the concept of "gender" during vocational training or during their professional development. In addition, only $7.7 \%$ of the teachers surveyed indicated professional literature as the source from which they first learned about the concept

"Gender". This fact can be explained either by the fact that teachers rarely turn to professional (pedagogical, psychological) literature, or by the fact that gender issues are poorly covered in it.

Analysis of answers to the question "Continue the phrase "Gender is ..." showed that $72 \%$ of the teachers surveyed have a more or less correct understanding of the concept of "gender" (differences by sex, gender, social gender, sex-role behavior, functions of men and women in society). $14 \%$ of respondents were unable to characterize this concept, and $13.5 \%$ have erroneous ideas about it. 
The views of the interviewed teachers about the gender approach in education are as follows: only $9 \%$ of respondents' answers correspond to the scientific interpretation of this concept (it is associated with taking into account the interests of students and equality in providing them with educational opportunities); $38 \%$ of teachers associate a gender approach in education only taking into account the gender of students in the educational process, $11 \%$ - with separate education, $3 \%$ - with the division of the class into boys and girls, $29 \%$ of teachers were unable to characterize this concept. Thus, the study showed a very low awareness of teachers in issues related to gender approach in education.

When analyzing the answers of the interviewed teachers regarding the need to implement a gender approach in education, the following results were obtained: $38.5 \%$ of teachers could not answer this question; $10.8 \%$ of the respondents do not see the need for its implementation at all; $18.5 \%$ - associate the need to implement a gender approach with the fact that boys and girls have different psychological and physiological apply a gender approach only in the case of individualization of education. Only one respondent (1.5\%) pointed to the need to implement a gender approach as a condition conducive to selfdetermination of schoolchildren.

Among the reasons that hinder the implementation of a gender approach in education, the interviewed teachers noted the unpreparedness of the school (15.4\%) (apparently the teachers meant the unpreparedness of the participants in the educational process), the lack of conditions for its implementation and the absence of such schools (14\%), lack of knowledge about him (4.6\%), inability to take into account the individual interests of each child (3.1\%), unpreparedness of society as a whole (3.1\%), different rates of development of boys and girls $(3,1 \%)$, large time costs and an increase in the workload of teachers in connection with its implementation (3.1\%), existing stereotypes (1.5\%), the predominance of women in society (1.5\%). In addition, $1.5 \%$ of respondents do not see any difficulties in the implementation of the gender approach, and $41.5 \%$ were unable to formulate the reasons that impede its implementation.

As the main areas of professional activity in which a teacher can use the gender approach most effectively, teachers most often singled out the classroom hour and educational work (23\%), physical education (18\%) and technology (10\%). Thus, the highlighted areas correspond to the traditional sex-role approach to teaching and upbringing, which may indicate that the interviewed teachers equate the sex-role and gender approaches.

The data obtained as a result of the questionnaire survey on the use of the gender approach by teachers in their pedagogical practice shows that $20 \%$ of teachers do not use it, $46 \%$ use only its individual elements, and only $8 \%$ actively use the gender approach in their activities. ...

Conclusions of the study and prospects for further research in this direction. So, the study showed that despite a fairly well-developed theory of the gender approach in pedagogical science, knowledge of this kind is practically not used in pedagogical practice, and the teachers we interviewed have rather vague ideas about the gender approach in education. and its application. In our opinion, this is due to the poor awareness of teachers about this approach. Thus, improving the qualifications of teachers and students of pedagogical universities in gender issues, their systematic information support, equipping with teaching aids in which gender issues would receive coverage, is, in our opinion, one of the urgent tasks of modernizing education. - nii and society. Its implementation could contribute to promoting the ideas of gender equality in society and wider dissemination of a gender approach in schools. 


\section{REFERENCES:}

1. Stolyarchuk L.I. Methodology of gender approach in pedagogical research / L.I. Stolyarchuk // Language of pedagogy in the context of modern scientific knowledge: materials of the All-Russian. methodologist. conference-seminar / Ch. ed. V.V. Kraevsky; Ed. A.A. Arlamov, R.V. Pochter - Volgograd; Krasnodar; M.: 2008. - P.P. 284, 232-238.

2. Shtyleva L.V. The gender factor in education: gender approach and analysis / L.V. Shtylev. - M.: PER SE, 2008. - P. 316.

3. Kamenskaya E.N. Gender approach in pedagogy: dis ... doct. ped. Sciences: 13.00.01 / E.N. Kamenskaya. - Rostov n / a, 2006.

4. Mitrofanova A.A. Gender approach in pedagogy / A.A. Mitrofanova // Introduction to Gender Studies sky features; $6 \%$ of teachers consider it necessary to give: manual for university students / Ed. I.V. Kostikova. - M.: Aspect Press, 2005. - P. 182-195.

5. Yarskaya-Smirnova E.R. Gender socialization in the education system: a hidden curriculum / E.R. Yarskaya-Smirnova / Clothes for Adam and Eve: Essays on Gender Studies / RAS INION, Saratov. State those. ounce Center for Social Policy and Gender Studies. - M., 2001. P. 93-111. - Access mode: http://www.eduaction.narod.ru/iarsk_paper.htm (date of access: 28.11.2015).

6. Kotlova T.B. Gender stereotypes in primary school textbooks / T.B. Kotlova, A.V. Smirnova// Women in Russian society. - 2001. - No. 3-4. - P. 53-61.

7. Kletsina I.S. Gender socialization: Textbook / I.S. Clecine. - SPB.: Publishing house RGPU im. A.I. Herzen, 1998. - P. 92.

8. Smirnova A.V. Gender socialization in a general education school: Author's abstract. dis. ... Cand. sociol. sciences. - N. Novgorod, 2005. - P. 25.

9. Karkishchenko E.A. Gender communication in the modern school / E.A. Karkishchenko // Language, Consciousness, Communication: Sat. articles / Otv. ed. V.V. Krasnykh, A.I. Izotov. - M.: MAKS Press, 2012. - Issue. 44-112 p. - P. 31-38.

10. Gender strategy of the Russian Federation (Draft). - M.: 2004. - P. 25.

11. Kon I.S. Man in a Changing World / I.S. Con. M.: Vremya, 2009. - P. 496.

12. Zdravomyslova-Stoyunina O.M. Society through the prism of gender concepts / O.M. Zdravomyslova-Stoyutina // Woman, gender, culture. - M.: 1999.

13. Popova L.V. Gender aspects of personality self-realization. Textbook for the special seminar / L.V. Popov. // M.: Publishing house "Promerey", 1996. - P. 42.

14. Aivazova S.G. Fundamentals of the methodology for recognizing and assessing discrimination against women in the labor market / S.G. Aivazov. Second edition, supplemented and revised. - M.: Eslan, 2007. - P. 112.

15. Gender asymmetry in the Russian system of higher education and its possible social consequences in the transition to a market economy. Part I. Methodology and methodology of sociological research / otv. ed. G. Sillaste - M.: FA, 2002. - P. 168.

16. Kostikova I.V. Prospects for gender education in Russia / I. Kostikova, A. Mitrofanova et al. // Higher education in Russia. - 2001. - No. 2. - P. 68-75.

17. Alexandrova N.V. Gender strategies in European education: Germany and France / N.V. Aleksandrova // Humanitarian education and social context: gender problems: materials of the Intern. scientific. conf. St. Petersburg, June 25-28, 2007 / otv. ed. O.V. Popov. SPb.: Ed. house St. Petersburg. state University, 2007. - P. 48-54. 
18. Kletsina I.S. Theoretical and methodological foundations of modern gender education / I.S. Kletsina // Gender studies in education: problems and prospects: collection of articles. scientific. Art. following the results of Intern. scientific-practical conf. Volgograd, 15-18 Apr. 2009. Volgograd: publishing house of VSPU “Change”, 2009. - P.P. 342, 49-53.

19. Shnyrova O.V. What does gender pedagogy give us? / O.V. Shnyrova // Gender pedagogy and gender education in post-Soviet countries: Collection of articles. materials of the International Summer School 2001. Ivanovo, 2002. - P. 294, 3-9.

20. Kostikova I.V. Fundamentals of gender pedagogy / I.V. Kostikova et al. // Woman in Russian society. 2000. No. 3. - P. 67-74.

21. Shtyleva L.V. Gender approach in education: Curriculum and guidelines for the course / L.V. Shtylev. Murmansk: Moscow State Pedagogical University, 2004. - P. 78.

22. Gender pedagogy and gender education in post-Soviet countries: Coll. materials of the International Summer School 2001. Ivanovo, 2002. - 294 p. P. 213-229.

23. Big psychological dictionary // Ed. Meshcheryakova B.G., Zinchenko V.P. M.: PrimeEvroznak, 2003. - P. 672. 